\title{
Situeret læring og praksisfællesskab
}

Cathrine Hasse introducerer Jean Lave

FORSKERINTRODUKTION

Laring foregair operalt som en konstant bevagelse der andrer viden, position og identitet $i$ samspil med omgivelserne. Jean Laves teorier om situeret laring og praksisfallesskaber äbner for nye spørgsmail til kønsforskningen.
Antropologen Jean Lave, der i dag er professor i pædagogik ved University of California i Berkeley, skriver sig ind i et næsten eksponentielt voksende felt, der under ét kan benævnes situeret læring (cf. Bredo 1997). Det nye læringsbegreb lægger vægt på læringens sociale konstruktion. Teorier om situeret læring insisterer på en opmærksomhed på relationer mellem folk, der handler, og den materielle verden, der handles i. Derfor er deltagelse og forståelse i praksis, dvs. læring, central (Lave $1993,5)$. Jeg vil i det følgende give en introducerende indføring i Laves teori om situeret læring i praksisfællesskaber, og dernæst søge at vurdere teorien ud fra et kønsperspektiv.

Situeret læring lægger sig mellem og som et svar på to andre tidligere teoretiske retninger indenfor læreprocesforskningen, behavioristerne og kognitivisterne. Hvor behaviorismen i sin mest ekstreme udformning har studeret kropsbevægelser uden bevidsthedens tankeprocesser, har kognitivis- 
men studeret tankeprocesser uden hensyn til kropsbevægelser (Bredo 1997, 3). I stedet for indlæring af formaliseret viden lægger den situerede teori vægt på læring som "engagement in changing processes of human activity" (Lave 1993, 12).

Af ældre og yngre inspirationskilder kan nævnes den kulturhistoriske aktivitetsteoretiske skole udsprunget af gruppen omkring den russiske psykolog Lev Vygotsky og dens moderne arvtagere i USA og Finland, Michael Cole og Ÿrjö Engeström. Den ældre amerikanske "learning by doing" pragmatiker John Dewey og praksislogikkens og habitus begrebets "fader", franskmanden Pierre Bourdieu, har også været væsentlige inspirationskilder.

Lave har været en af de primære drivkræfter bag koblingen af praksis og læring ikke mindst med teorien om praksisfællesskaber. Antagelsen er, at al læring finder sted som skiftende deltagelse i igangværende social praksis i et praksisfællesskab. Teorien er udviklet sammen med kollegaen Etienne Wenger og kan kort summeres i udtrykket "legitimate peripheral participation in communities of practice" hentet fra den i læringsforskningssammenhænge så indflydelsesrige bog Situated Learning, Legitimate Peripheral Participation (1991).

Gennem legitim, perifer deltagelse tilegner en nyankommen sig gradvist et praksisfællesskabs væsentlige færdigheder, kundskaber og værdier og bevæger sig fra en perifer deltagelse til at blive et fuldgyldigt medlem af fællesskabet. Deltagelse er defineret som muligheden for at lære delvist eller fuldt medlemsskab, hvilket igen defineres som et spørgsmål om legitimitet. I praksisfællesskabet er alle - selv fuldt ud deltagende medlemmer - perifere forstået som multible og varierende måder at være "located in the fields of participation defined by a community" (Lave \& Wenger 1991, $35)$.

Praksisfællesskabet er ikke en veldefineret gruppe, men består af deltagere i aktivitetssystemer, hvor deltagerne deler en forståel- se af, hvad de gør, og hvad det betyder for deres liv (Lave \& Weger 1991, 98). Praksisfællesskabet er ikke defineret ved at have et "center", hvor al viden samles i frellesskabet, men ved stadigt skiftende positioner $i$ forhold til fuldt medlemskab. Hvor læring konventionelt har været opfattet som "transmission af viden", der indoptages i interaktionen mellem lærer og elev, understreger teorien, "...the relational interdependency of agent and world, activity, meaning, cognition, learning and knowing" (ibid., 50).

Vi kan være situeret forskelligt i forhold til sådanne "fields of participation". Det er, når vi flytter os, at perspektiver ændres og der udvikles identiteter og medlemsskabsformer. Det epistemologiske standpunkt fører Lave til en radikal definition af viden. Viden er ikke noget, et enkelt individ kan tilegne sig isoleret fra en social praksis. Følgelig er viden ikke noget, nogen har tilegnet sig kognitivt, mens andre ikke har skaffet sig denne viden. Deltagernes viden afhænger af, hvilken kontekst de indgår i. Viden opstår, siger Lave, i de sociale relationer "not in the master but in the organisation of the community of practise of which the master is a part" (Lave \& Wenger 1991, 94).

Henvisningen til en "master" kan forklares ud fra den grundmetafor, der har været styrende for Laves udvikling af sit teoretiske begrebsapparat. I 1970erne udførte Lave et feltarbejde blandt 100 mestre og 150 lærlinge i Skræddergyden i Monrovia, Liberia, hvor Vai og Gola-skrædderne arbejdede. Her tilbragte hun mange timer med at studere daglige hændelser og lytte til den stedlige sladder, mens hun gradvist fik en forståelse af, hvad mesterlære drejer sig om.

Et vigtigt aspekt af skrædderundersøgelsen fokuserede på den påstand, karakteristisk for dualistiske læringsteorier, at mulighederne for kreativ aktivitet og produktion af "ny viden" er begrænset til bestemte former for uddannelse (Lave 1999, 40). Læring i et uddannelsessystem skulle garan- 


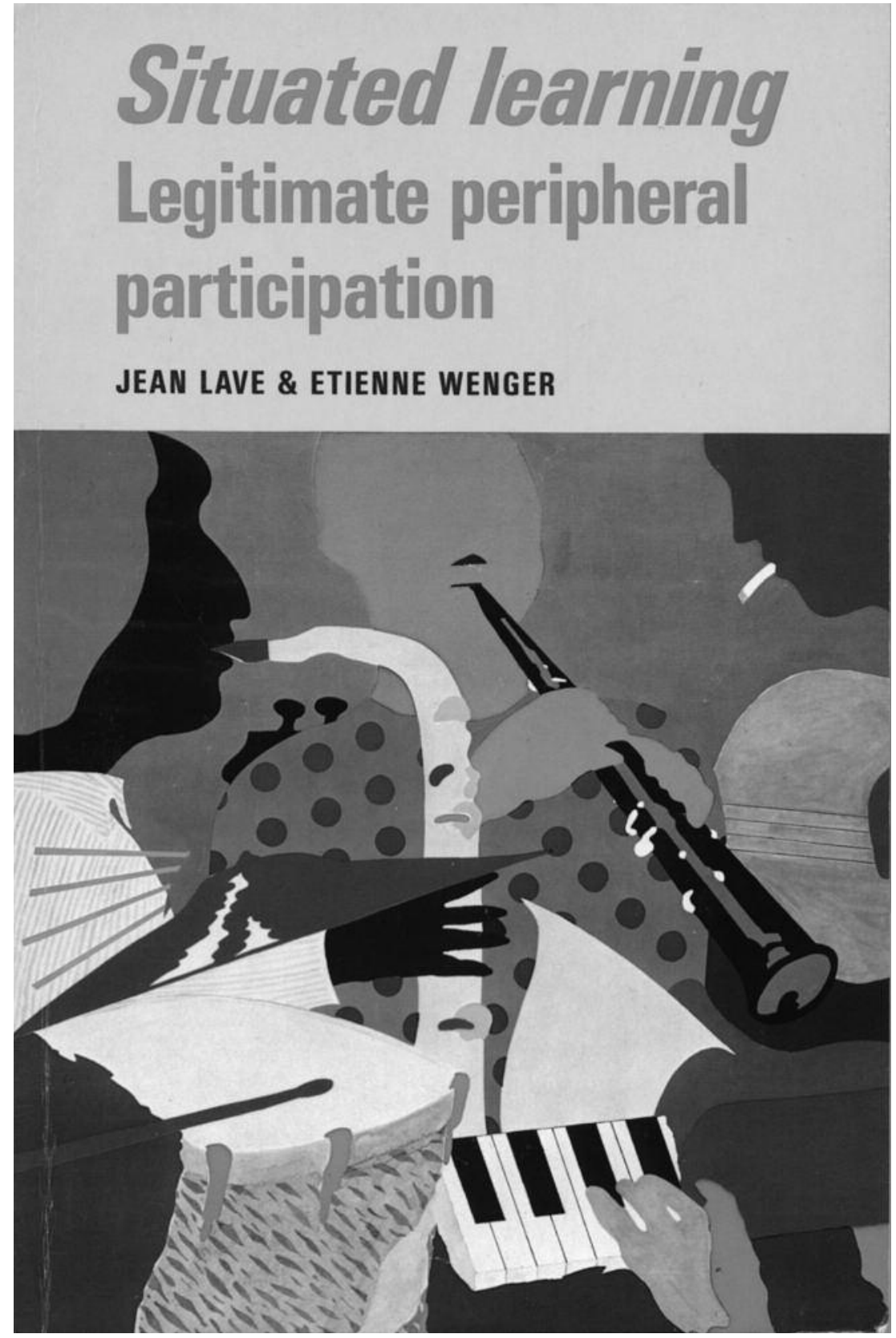

Illustrationen er af Bent Karl Jacobsen 
tere udviklingen af sådanne evner, mens mesterlæren ikke gør det. Antagelsen har været, at mesterlære blot reproducerer eksisterende praksis i snæver forstand.

I løbet af feltarbejdet indså Lave, at det er umuligt at lære at tilskære bukser uden at lære om andre politiske, økonomiske og kulturelle praksisser, hvori såvel bukser som lærlingen indgår. Arbejdet med bukserne lærte lærlingen forskellige former for rangordner og relationen mellem formel/uformel, det social betydningsfulde og det mindre væsentlige. Gennem aktiviteterne knyttet til mesterlæren lærer lærlingen, hvordan man skaber sig en tilværelse, og hvordan man selv med tiden kan opnå respekt som mester. I denne læringspraksis (og den teoretiske forståelse af denne praksis) nedbrydes skellet mellem læring og handling.

Den "uformelle læring" i værkstedet kan ikke reduceres til en reproduktiv erhvervelse af konkret arbejdsviden. Lærlingene lærer på yderst varierede måder, der involverer komplicerede relationer mellem praksis, rum, tid, kroppe, sociale relationer og livsforløb (ibid., 4l).

En videreudvikling af feltarbejdets teoretiske perspektiver førte blandt andet til, at Lave blev involveret i nye studier af socialt situeret hverdagsmatematik i Liberien. Gennem disse og andre studier når hun til den konklusion, at det ikke kun er den uformelle side af livet, der består af indviklet kontekstindlejret og situeret aktivitet; der er ikke andet (ibid, 43, Lave 1988). Læring er ikke forbeholdt særlige institutioner eller situationer. Den foregår overalt som en bevægelse gennem det kulturelt formede hverdagsliv, der konstant ændrer vores forståelse af den sociale praksis, vi indgår i (Lave 1996, 6). I denne konstant bevægelige proces ændres position, viden og identitet fortløbende $i$ et relationelt samspil med praksisfællesskabet. Det vi først og fremmest lærer i praksis er ikke formaliseret viden, men etableringen af en identitet knyttet til fællesskabets aktiviteter (Lave \& Weger, 1991).
Perspektivet understreger, at identitet er en social proces skabt gennem deltagelse. Det er ud fra dette perspektiv, Lave efter min opfattelse kan finde anvendelse i kønsforskningen, skønt det ikke er den vinkel hun selv lægger på sit arbejde.

Med Laves epistemologi in mente bliver det interessant at spørge til kønnets status i skiftende kontekster. Det spørgsmål, der rejser sig, er: Hvad er det, kvinder lærer gennem deltagelse i praksisfællesskaber, der er en "kvindelig" identitet? Det kunne give en mere fleksibel tilgang end gængs socialiseringsteori at se kønsidentitet som dannet i relation til læring $\mathrm{i}$ et praksisfællesskab dvs. læring knyttet til sociale aktiviteter. Eftersom viden, ifølge Lave, er knyttet til praksisfællesskaber, kunne det ud fra den foreliggende teoretiske indfaldsvinkel være nærliggende at forestille sig, at det også kunne gælde kønnet. En nærmere undersøgelse ville indebære spørgsmålet om, hvorvidt kvinder indgår i de samme praksisfællesskaber som mænd. Køn optager, som nævnt ikke Lave.

I de fem eksempler fra hele verden, der fremhæves som eksempler på praksisfællesskaber i Situated Learning, nævnes medlemmernes køn kun få steder. I Yucatec bevæger jordemødrene sig over mange års praksis fra perifer deltagelse til fuld deltagelse i jordemoderens daglige praksis. Der er en specifik angivelse af jordemoderens køn ("all women") (Lave \& Wenger 1991, 66), og vi får at vide, at den lille Maya pige tilegner sig viden om mysterierne ved en jordemoders praksis gennem sin deltagelse $i$ det daglige liv. Hun făr ingen formel undervisning, men lærer som et aspekt af sin daglige tilstedeværelse, mens jordemoderen er i gang med sine gøremål. Samme fremgangsmåde følger Laves mandlige skræddere, der som Maya-pigerne starter med at se på. Derefter tilegner de sig gradvist en inkorporeret viden om at sy klæder ved selv at deltage i tilskærings- og syarbejdet. Flådens kvartermestre lærer som de andre to grupper af deres mere erfarne kolleger, 
skridt for skridt. Vi får indirekte at vide, at der nok er tale om mænd i sætningen "For a young man entering the quartermaster rate, there are many sources about the work to be done (ibid., 73). Alkoholikerne i Nondrinking Alcoholics (A.A.) rekonstruerer deres identiteter i det nye praksisfællesskab, når alkoholikeren konstruerer sin personlige livshistorie og dermed betydningen af sine fortidige og fremtidige handlinger for de øvrige medlemmer. Heller ikke her fremhæves kønnet specifikt, men vi făr at vide, at der er tale om "men and women", (ibid., 80), men ikke om der er kønnet forskel på, hvorledes deres identiteter forandres i mødet med A.A. Endelig er der slagterlærlingene, der ikke får lov "selv at prøve", men modtager teoretisk undervisning i udskæringsteknikker med det resultat, at de ikke lærer, hvordan man gør. Disse lærlinge omtales som "students", “apprentices" og kønnes indirete med sætninger som "All those guys know so much about meat cutting, and I don t know anything" (ibid., 78).

Lave og Wenger opererer her med hele grupper fremfor enkeltindivider, skønt teorien lægger op til en nærmere undersøgelse af relationerne inden for et praksisfællesskab og individets bevægelser mellem praksisfællesskaber. Hvis Laves praksisfællesskaber skal være mere end velkendt socialiseringsteori hældt på nye flasker (hvad nogle har kritiseret hende for - se Rasmussen 1999), så må de kunne bringe os nærmere en forståelse af eksempelvis kønnets betydning som struktureringsprincip på tværs af de mange praksisfællesskaber, hvori der indgår mænd og/eller kvinder. I de praksisfællesskaber, hvori der kun indgår kvinder eller mænd, kunne man spørge til, hvorvidt der i forbindelse med kønsspecifikke aktiviteter også udvikles kønsspecifikke identiteter. I praksisfællesskaber, hvori der indgår både kvinder og mænd, kunne det at medtænke kønnet muligvis være én indfaldsvinkel til at undersøge, om mænd og kvinder under disse betingelser udvikler ens identiteter. At fokusere på kønnet kunne også være en måde at opløse praksisfrllesskabet som samlet gruppe på, men der er mange andre mulige og formentlig indbyrdes konstituerende stratifikationer.

Som Kirsten Grønbæk Hansen har bemærket, mangler der et livshistorie-aspekt i Laves teori om situeret praksis (Grønbæk Hansen 1998). Når den enkelte forsvinder ud af det teoretiske perspektiv, forsvinder også den enkeltes køn, og den betydning det kunne have at være kønnet i den aktuelle læreproces i et praksisfællesskab. Der mangler i det hele taget noget teoriudvikling, før Laves fascinerende tanke-sæt kan finde vej til en anvendelse i forbindelse med en konkret empirisk kønsanalyse. Hvorledes følger man eksempelvis som forsker helt konkret, hvorledes positioner ændres og en kønsidentitet udvikles $i$ et relationelt samspil med et givet praksisfællesskab?

Det allermest brugbare ved Lave for kønsforskningen er efter min mening de spørgsmål, der fremtvinges af hendes epistemologiske afsæt. Laves egen udpegning af praksisfællesskabet som identitetskonstituerende kunne eksempelvis føre til overvejelser over om kønnet følger med, når vi skifter praksisfællesskab. Hvis situeret læring er "the historical production, transformation and change of persons" (Lave \& Wenger 1991, 51), er kønsidentiteter så et stabilt fænomen på tværs af praksisfællesskaber? Kan relativt stabile kønsforskelle i givet fald forklares ud fra fællestræk mellem praksisfællesskaber? Spørgsmål Lave ikke selv søger at give svar på, fordi hun ikke selv rejser dem, hvilket jo ikke behøver at afholde os fra at gøre det.

\section{LITTERATUR}

- Bredo, Eric (1997): “The Social Construction of learning. Introduction", in Gary D. Phye (ed.): Handbook of Academic Learning - Construction of Knowledge, pp 3-45, Academic Press, San Diego. 
- Lave, Jean (1999): “Læring, mesterlære, social praksis", in K. Nielsen og S. Kvale (eds.): Mesterlare - Laring som social praksis, pp.35-53, Hans Reitzels Forlag, København.

- Lave, Jean (1993): "The practice of learning" in S. Chaikling og J. Lave (eds.): Understanding practice. Perspectives on activity and context, Cambridge University Press, Cambridge.

- Lave, Jean \& Wenger, Etienne (1991): Situated Learning, Legitimate Peripheral Participation, Cambridge University Press, Cambridge.

. Grønbæk Hansen, Kirsten (1998): "Er læring mere end situeret praksis?", in Dansk Padagogisk Tidsskrift, (2): 6-16.

. Rasmussen, Jens (1999): "Mesterlære og den almene pxdagogik", in K. Nielsen og S. Kvale (eds.): Mesterlare - Laring som social praksis, pp. 35-53, Hans Reitzels Forlag, København.

\section{ØVRige LAVE-PUBlikationer}

- Rogoff, Barbara \& Lave, Jean (1984) Everyday cognition: its development in social context, Barbara Rogoff and Jean Lave (eds), Harvard University Press, Cambridge, Mass.

- Lave, Jean (1988): Cognition in practice: Mind, Mathematics, and Culture in Everyday Life, Cambridge University Press, New York.

- Lave, Jean (1988): "Formidling eller praktisk forståelse", in Udkast, nr.2, pp. 150-180.

. Lave, Jean \& Kvale, S. (1995): "What is anthropological research?" An interview with Jean Lave by Steinar Kvale, in Qualitative Studies in Education, 8, 219-228.

Cathrine Hasse, Ph.d-stipendiat, Institut for Antropologi, Københavns Universitet 